\title{
Living, collective and political organisms for construction of the attributes of the National Oral Health Policy
}

\author{
Organismos vivos, coletivos e políticos pela construção \\ dos atributos da Política Nacional de Saúde Bucal
}

Alexandre Fávero BULGARELLI' iD https://orcid.org/0000-0002-7110-251X

\begin{abstract}
The last few decades have witnessed a growth in the value of dentists as health professionals as they act as protagonists in the construction of public health policies. This change comes from powerful and representative dentists in the Unified Health System (acronym in Portuguese is SUS). This short theoretical essay aims to bring the reader closer to the attributes necessary for the building of a social policy and draws a parallel with the National Oral Health Policy (acronym in Portuguese is PNSB). Issues such as contextoriented health policy and the National Oral Health Policy associated with the attributes of a social policy are presented in a narrative and reflective manner. In this process, the exercise of citizenship is demonstrated, emphasizing the importance of the collective role and policy of dentist surgeons in the stages of health policies in Brazil
\end{abstract}

Indexing terms: Health policy. Public health. Social participation.

\section{RESUMO}

A valorização do cirurgião dentista como um profissional da saúde que pode ser protagonista na construção de políticas públicas de saúde vem se fortalecendo nas últimas décadas. Este fortalecimento se dá pela atuação potente e representativa da odontologia no Sistema Único de Saúde. Este breve ensaio teórico tem o objetivo de aproximar o leitor aos atributos necessários para a construção de uma política social e traçar um paralelo com a Política Nacional de Saúde Bucal. Deste modo, questões como contextos produtores de uma política de saúde e a Política Nacional de Saúde Bucal associada aos atributos de uma política social são apresentadas de forma narrativa e reflexiva. Neste processo o exercício de cidadania se faz presente, ressaltando a importância do papel coletivo e político do cirurgião dentista no ciclo vivo das políticas de saúde no Brasil.

Termos de indexação: Política de saúde. Saúde pública. Participação social.

\section{INTRODUCTION}

Revisiting his twenty-year doctoral thesis after being publicly defended, the philosopher and doctor Frenchman
Georges Canguilhem, reiterates that health and illness are manifestations of life. In addition, the aforementioned sociologist states that life is a social manifestation that presents itself through biological organisms who are

$\because \cdots$

1 Universidade Federal do Rio Grande do Sul, Programa de Pós-Graduação em Saúde Coletiva. Faculdade de Odontologia, Departamento de Odontologia Preventiva e Social. Rua Ramiro Barcelos 2492, Santa Cecilia, Porto Alegre, RS, Brasil. Correspondence to: AF BULGARELLI. E-mail: <alexandre.bulgarelli@ufrgs.br>.

$\boldsymbol{v} \boldsymbol{\nabla} \boldsymbol{v}$

How to cite this article

Bulgarelli AF. Living, collective and political organisms for construction of the attributes of the National Oral Health Policy. RGO, Rev Gaúch Odontol. 2021;69:e20210030. http://dx.doi.org/10.1590/1981-8637202100302020033 
collective and interactive [1]. From this assumption, a social organism, too, can be understood as a political body, that is, a body that develops policies. In other words, a social organism is one with strong political and emancipatory potential [2]. This political body/organism, which goes through interactive, participatory, and social processes, can guide and translate health needs and problems to solve proposals and guide state policies. It happens when acting in the field of collective health. The Georges Canguilhem's writing deals with making politics a manifestation of life of collective organisms.

This theoretical essay is presented in the form of a context-oriented socio-historical narrative, with the support of classic authors of collective health and collective oral health. Throughout this narrative, some policies involving the Unified Health System (acronym in Portuguese is SUS) are addressed, and notes and inferences by the author are presented. Thus, the way this text is written is similar to the spoken form of the language. The object of this theoretical essay is a set of concepts regarding the construction of public and social policies [3,4]. Moreover it also goes through the National Oral Health Policy (acronym in Portuguese is PNSB) [5], its approximations with the National Policy of Primary Care and the weaknesses found at the federal level in the implementation of the National Policy for Continuing Education in Health (Acronym in Portuguese is PNEP) $[6,7]$. It should be noted that the scenario of this study is the SUS.

The goal of this brief theoretical and reflective essay is to present a current interlocution between the exercise of citizenship and the construction of the PNSB. Specifically, this text presents a parallel between the necessary attributes for the construction of a social policy and the structuring axes of the PNSB that are configured as a reflection of the participation and social collective interaction of living organisms. Thus, it is believed that this essay can bring the reader closer to the attributes necessary for the construction of a social policy and therefore trace a parallel with the PNSB.

\section{Context producers of a health care policy}

The Pan American Organization of Health presents in their speech, a practical advisory on public policies so that a country can effectively diminish its social inequalities and improve the quality of life of their populations to meet public health demands. In other words, there are public policies that must be at the center of a country's health actions in order for them to reach satisfactory levels of health in their population. In this context, it can be understood that public policies are a set of devices, measures, and procedures that reflect the state's care orientation to their populations, or rather, their citizens. In this process, social constructionists find it important to highlight that policy related aspects, public health actions, citizenship, and process perspectives in healthcare are not isolated. It is here, that we need to contextualize such aspects.

The process of healthcare is a complex system that has developed over centuries. The end of the Middle Ages and the fall of the feudal regime is the moment in history when the beginning of urbanization of cities (burgos) and precarious health conditions led to the emergence of political movements that translated into compensatory and sanitary measures for workers who were entangled in these situations [8]. This is the moment when the idea of public health policy, from a collective perspective, came to present itself. By the end of the 19th century it was observed that the industrial revolution, the emergence of Social Medicine, as well as the presence of thinkers like Karl Marx, brought out the struggle of collective organisms [1], in order to bring about public improvements to their everyday living conditions and work. It was at this moment that the concept of citizenship arose. As highlighted by Jairnilson Pain and Naomar de Almeida Filho, through their interlocutors, citizenship is the political dimension of the subjects and passes through social relations that build actions that can guide the practices of the State from the perspective of the health of their populations [8].

The construction of the meanings of health, disease, and care throughout history bring to light the fact that citizenship as an exercise of social participation is part of this historic process. At present in Brazil, although it is in need of strengthening, there is social participation in deliberations on issues involving the oral health of the Brazilian population [9]. Social participation in Brazil is one of the premises of the management of SUS $[10,11]$. For this, the exercise of citizenship is also crucial to allow participation in formulating health policies. It should be noted that, health policies in Brazil are understood as social policies since access to health is part of the conception of Brazilian social security such as some contexts and issues of the European model of social security in the post-war era (Welfare State). Therefore, the SUS, as a potential 
framework of health policies, is legitimized by the exercise of citizenship of Brazilians. It was in the context of the redemocratization of the country, that the collective body found a set of favorable conditions with a lively and cyclical process, that conformed to the SUS in the late 1980s. This process of redemocratization was wrapped in a perspective of expanded healthcare, social participation, retirement health, and the understanding of the social and political capital of health.

The production of a social policy is somewhat cyclical. Góes \& Moyses [4], contextualize such production as a policy cycle, linked to the social and historical construction of collective oral health [12]. Thus, political awareness is constantly needed so that issues of oral health are a topic of discussion in the health policy agenda in Brazil. It is worth noting that throughout its existence, the PNSB has improved (200\% increase in access to dental services in care) considerably in its access to oral health services which reflects in the improvement of health indicators of Brazilians [13-15]. Nationally, there is also an $118 \%$ increase in the number of municipalities with oral health teams [16].

The start of the cycle for the construction of guidelines for oral health actions, is made by the perception of society itself (collective organism, society, and their oral health needs). Such needs allow one to identify problems in the health services. In taking such issues (problems) to public debate, society collectively builds a way of sustaining decisions taken within this cyclical process.

When a problem is brought to public debate and included in the agenda for discussion on policies of the country, it helps initiate the formulation of guidelines and constructs a theoretical basis. Structured guidelines, are aimed at making decisions in order to implement health-care models and thus provide dental services to the population. Implementing these actions and practices, the cycle closes with the permanent evaluation of these actions which in turn restarts through new sensibilities. The cycle thus continues. It is important to highlight that issues of humanizing oral health-care, as well as reduction of mutilation procedures and increase of preventive procedures reflect the satisfaction of SUS users in the face of care and treatment received $[17,18]$. Thus, actions in oral health, oriented by the PNSB demonstrate the effectiveness of this policy and strengthen the understanding that such a policy is vital for the health of Brazilians.

\section{The national oral health policy and the attributes of a social policy}

In view of the contexts that led to the formulation of the health policies presented, and following the assumptions proposed by Fleury \& Ouverney [19] to think about social health policies, we will present some articulations and considerations that address guidelines for a national oral health policy as analyzers of a national political and social institution called Collective Oral Health. In this process, the understanding of politics comes across as regulatory, but as Neto \& Frazão assert [20], a policy is an apprentice ready to adapt with the advancement of scientific evidence and the needs arising from the contemporaneity.

In life cycle and dynamic health policies, some attributes are present. Policies are formulated through the delineation of objectives, the building and implementing of strategies, the performance of policy roles, the construction of arenas and negotiation with channels, the foundation of institutional and theoretical frameworks, and finally the construction of an ethical imperative.

The PNSB cycle begins with the exercise of citizenship, with the aim providing the Brazilian population well designed democratized access to oral health services, and integration of oral health actions as something legitimated within the SUS. With this aim in mind, a set of guidelines that converged as a political proposal entitled 'Smiling Brazil' was initiated to improve the quality of life of a portion of the Brazilian population who had no access to oral health services. This led to organization of the work processes of oral health teams in Brazil. It is worth noting that the effective work of oral health teams is guided by this set of guidelines [21]. However, almost two decades after the emergence of oral health policy guidelines it is still difficult to integrate oral health teams and health teams of the family [22].

The strategies which were thought, built, and employed in 2004, the year in which the PNSB entered the country, made it possible to build a model of oral health care. This model has been structured into integral care, keeping in mind the longitudinality of care involving diagnosis, healing, treatment, and the control of oral diseases, as well as the promotion of health and prosthetic rehabilitation. This model of attention is based on and resembles the PNAB [6], as against the assumptions of primary care, brought by Starfield [23], because oral health care is 
carried out through care lines and care flows (reference and counter-reference) within an articulated network of services. In addition to these aspects, the strategies built by the PNSB are fundamental in surveying the health conditions oral care model of the Brazilian population to guide the oral health care model. These strategies include providing basic care through the family health strategy; employing care specialists in dental specialty centers, with dental surgeons having the right to express themselves at the hospital level and having autonomy to serve patients in oral oncology care; and requesting hospitalizations and representation in the management colleges. In addition to these strategies, it should be noted that the policy brings together actions of surveillance, prevention and health promotion collectives as well as strategies for the practice of continuing education. This intersects with the PNEP [7] that reinforces the importance of SUS dentist surgeons' participation in the management, learning at work, and understanding of dental care and social control [24]. When collective organisms play their political roles, social control is exercised in two important situations. First, health professionals, and specifically oral health professionals and workers, through health boards play political roles in deliberations on health needs and problems in their territories, be it at the micro or macro level. Second, the holding of historic national health conferences strengthen the social role of collective oral health and act as the subjective link between SUS users and oral health teams $[25,26]$.

Conferences also arenas as channels for political negotiations and living spaces. All the oral health conferences that took place in 1986, 1993, and 2004 discussed the oral health issues of Brazilians as a topic of importance in SUS, with universal access, integral care with committed professionals, and working processes compatible with the realities of the models, assistance, and social participation.

The attribute that shows the importance of institutional and theoretical frameworks in the PNSB contradicts the assumptions of the SUS, where universal access to all instances of oral health care, equity as the factor that guides the need for care, and comprehensive care intertwine forming an institutional framework for the oral health actions present in the policy. The institutional frameworks therefore help in the governing and implementation of policies [27]. It should be noted that theoretical frameworks are auxiliaries for the understanding of reality [26]. In this context, the institutionalization of collective oral health, as a field of practice and a coconstruction of the autonomy of users, is articulated within the guidelines of the National Policy of the Health Promotion (Acronym in Portuguese is PNPS) $[5,28,29]$.

The ethical imperative in the construction of a social policy turns to social inclusion and the possibility of exercising citizenship. In the PNSB, such facts are achieved by democratizing user care and through the possibility of user representation at health boards [11]. The redemption of participation as a management tool, is also present in the PNSB where collegiate management models allow the legitimate linking of the user to the services with the aim of guiding assistance practices in which their participation has decision-making value. Therefore, PNSB is something social that is constructed through the attributes of a public, social, and health policy for Brazilians.

\section{FINAL CONSIDERATIONS}

The exercise of citizenship is done by collective organisms. This theoretical essay shows that such organisms/bodies are political too. Thus, political organisms make social movements that generate agendas, arenas, and decision-making. It is also considered that the guidelines for the Brazilian National Oral Health Policy establish themselves as something that materialize the facts of a social construction that happens in a lively way through the interlocution of living organisms, collectives, and politics. Therefore, dentists are also political organisms fundamental to Brazilian public health!

\section{REFERENCES}

1. Canguilhem G. O normal e o patológico. Rio de Janeiro: Forense Universitária; 2002.

2. Safatle V. O que é uma normatividade vital? Saúde e doença a partir de Georges Canguilhem. Scientiae Studia. 2011;9(1):11-27.

3. Cayetano MH, Carrer FCA, Gabriel M, Martins FC, Pucca Jr GA. Política Nacional de Saúde Bucal Brasileira (Brasil Sorridente): Um resgate da história, aprendizados e futuro. Univ Odontol. 2019;38(80):1-23.

4. Goes PSA, Moysés SJ. Planejamento, gestão e avaliação em saúde bucal. Porto Alegre: Artes Médicas; 2012.

5. Brasil. Ministério da Saúde. Diretrizes da Política Nacional de Saúde Bucal. Brasília: Ministério da Saúde; 2004 [cited 2019 Nov 10]. Disponível em: <https://bvsms.saude.gov.br/bvs/ publicacoes/politica_nacional_brasil_sorridente.htm> 
6. Morosini MVC, Fonseca AF, Lima LD. Política Nacional de Atenção Básica 2017: retrocessos e riscos para o Sistema Único de Saúde. Saúde Debate. 2017;42:11-24. http://dx.doi. org/10.1590/0103-1104201811601

7. Gonçalves CB, Pinto ICM, Grança T, Teixeira CF. A retomada do processo de implementação da Política Nacional de Educação Permanente em Saúde no Brasil. Saúde Debate. 2019;43(especial 1):12-23. http://dx.doi.org/10.1590/010311042019s101

8. Pinto, et al. Ciclo de uma política pública de saúde: problematização, construção da agenda, institucionalização, formulação, implementação e avaliação. In: Pain JS, AlmeidaFilho N. Saúde coletiva teoria e prática. Rio de Janeiro: Medsi; 2013.

9. Andraus SHC, Ferreira RC, Amaral JHL, Werneck MAF. Organization of oral health actions in primary care from the perspective of dental managers and dentists: process of work, planning and social control. RGO, Rev Gaúch Odontol. 2017;65(4):335-343. http://dx.doi.org/10.1590/1981863720170002000083354

10. Brasil. Lei $n^{\circ}$ 8.080, de 19 de setembro de 1990. Lei Orgânica da Saúde. Dispõe sobre as condições para a promoção, proteção e recuperação da saúde, a organização e o funcionamento dos serviços correspondentes e dá outras providências. Brasília; set. 1990.

11. Brasil. Lei 8.142, de 28 de dezembro de 1990. Dispõe sobre a participação da comunidade na gestão do Sistema Único de Saúde (SUS) e sobre as transferências intergovernamentais de recursos financeiros na área da saúde e dá outras providências. Brasília; dez. 1990.

12. Soares C L M, Paim J, Rossi T A, Chaves S. O espaço da saúde bucal coletiva: contribuições para compreensão da formulação e implementação das políticas de saúde bucal no Brasil. In: Chaves SCL, organizador. Política de saúde bucal no Brasil: teoria e prática. Salvador: EDUFBA; 2016. p.13-46.

13. Chaves SC, Almeida AM, Rossi TR, Santana SF, Barros SG, Santos CM. Política de Saúde Bucal no Brasil 20032014: cenário, propostas, ações e resultados. Ciênc Saúde Colet. 2017;22:1791-803. http://dx.doi.org/10.1590/141381232017226.18782015

14. de Lorena Sobrinho JE, de Lima Martelli PJ. Saúde bucal no Brasil: análise do ciclo da política. Univ Odontol. 2019;38(80). http://dx.doi.org/10.11144/Javeriana.uo38-80.sbba

15. Junior GAP, Gabriel M, de Almeida Carrer FC, Junior MP, de Lucena EHG, de Melo NS. Acesso e cobertura populacional à saúde bucal após a implementação da Política Nacional de Saúde Bucal Brasil Sorridente. Tempus Actas Saúde Colet. 2020;14(1):29-43. http://dx.doi.org/10.18569/tempus. v14i1.2629

16. Gabriel M, Cayetano MH, Chagas MM, Araujo MED, Dussault G, Pucca Junior GA, et al. Mecanismos de ingresso de dentistas no SUS: uma agenda prioritária para o fortalecimento do Brasil Sorridente. Ciênc Saúde Colet. 2020; 25:859-868. http://dx.doi.org/10.1590/1413-81232020253.14532018
17. Moimaz SA, Lima AM, Garbin CA, Corrente JE, Saliba NA. Avaliação do usuário sobre o atendimento odontológico no Sistema Único de Saúde: uma abordagem à luz da humanização. Ciênc Saúde Colet. 2016;21(12):3879-3887. http://dx.doi.org/10.1590/1413-812320152112.12672015

18. Stein C, Santos KW, Condessa AM, Celeste RK, Hilgert JB, Hugo FN. Presença de Centros de Especialidades Odontológicas e sua relação com a realização de exodontias na rede de atenção de saúde bucal no Brasil. Cad Saúde Pública. 2020;36:e00054819. http://dx.doi.org/10.1590/0102$311 \times 00054819$

19. Fleury S, Ouverney AM. Política de saúde: uma política social. In: Giovanella L, Escorel S, Lobato LVC, Noronha JC, Carvalho Al, organizadores. Políticas e sistema de saúde no Brasil. Rio de Janeiro: Editora Fiocruz; 2008. p.23-64.

20. Souza Neto AC, Frazão P. Liberdades, direitos, políticas públicas e a fluoretação da água. Rev Saúde Pública. 2020;54:51. http://dx.doi.org/10.11606/s1518-8787.2020054001804

21. Flório FM, Lourenço MB, Oliveira AMG, Zanin L. Rotina de trabalho da equipe de saúde bucal sob a ótica do cirurgião dentista. RGO, Rev Gaúcha Odontol. 2017;65(4):344-351. http://dx.doi.org/10.1590/1981-863720170002000093441

22. Scherer $\mathrm{Cl}$, Scherer MDA, Chaves SCL, Menezes ELC. O trabalho em saúde bucal na Estratégia Saúde da Família: uma difícil integração? Saúde Debate. 2018;42(especial 2):233-246. http://dx.doi.org/10.1590/0103-11042018S216

23. Starfield B. Atenção primária: equilíbrio entre necessidades de saúde, serviços e tecnologia. Brasília: Unesco, Ministério da Saúde; 2002.

24. Ceccim RB, Feuerwerker L. O quadrilátero da formação para a área da saúde: ensino, gestão, atenção e controle social. Physis: Rev Saúde Colet. 2004;14(1):41-65.

25. Narvai PC. Saúde bucal coletiva: caminhos da odontologia sanitária à bucalidade. Rev Saúde Pública. 2006;40:141-147.

26. Pires FS, Botazzo C. Organização tecnológica do trabalho em saúde bucal no SUS: uma arqueologia da política nacional de saúde bucal. Saúde Soc. 2015; 24(1):273-284. http://dx.doi. org/10.1590/S0104-12902015000100021

27. Chaves S, Moysés S. Política e saúde: conceitos básicos e abordagens teórico-metodológicas para análise política em saúde bucal. In: Chaves SC, organizador. Política de saúde bucal no Brasil: teoria e prática. Salvador: EDUFBA; 2016. p.3-46.

28. Campos RTO, Campos GWS. Co-construção de autonomia: o sujeito em questão. Tratado Saúde Colet. 2006;1:669-688.

29. Malta DC, Silva MMAD, Albuquerque GM, Lima CMD, Cavalcante T, Jaime PC, et al. A implementação das prioridades da Política Nacional de Promoção da Saúde, um balanço, 2006 a 2014. Ciênc Saúde Colet. 2014;19:4301-4312. http:// dx.doi.org/10.1590/1413-812320141911.07732014

Received on: 30/3/2020 Final version resubmitted on: 11/9/2020 Approved on: 5/10/2020 